\title{
Pulmonary atresia with ventricular septal defect
}

INSERM

\section{Source}

INSERM. (1999). Orphanet: an online rare disease and orphan drug data base. Pulmonary atresia with ventricular septal defect. ORPHA:1207

Pulmonary atresia with ventricular septal defect (PA-VSD) is a rare cyanotic congenital heart malformation characterized by underdevelopment of the right ventricular outflow tract and atresia of the pulmonary valve, ventricular septal defect (VSD) and pulmonary collateral vessels. Clinical features depend on the anatomic variability of the lesion and patients may be minimally symptomatic, severely cyanotic or may develop congestive heart failure. PA-VSD may represent a severe form of T etralogy of Fallot (see this term). 